\title{
Effect of Service Quality on the Member Satisfaction of Cooperative BMT Trans Mekar Sari Mandiri at Tanjung Lago District Banyuasin Regency South Sumatera
}

\author{
Sriati $^{1}$, Ari Siswanto ${ }^{2}$, Mulyanto $^{3}$, Yuniarti $^{4}$ \\ \{sriati28@gmail.com¹, ari_sisw58@yahoo.co.id ${ }^{2}$, marius_mulyanto@yahoo.co.id ${ }^{3}$, \\ titi06612@gmail.com $\left.{ }^{4}\right\}$ \\ Universitas Sriwijaya, Indonesia ${ }^{1,2,3,4}$
}

\begin{abstract}
Cooperative is a business entity that based on kindship and providers services to the members. Service quality of a cooperative affects the members' satisfaction. The existence of good service quality is one of the reasons for members to join and contribute to cooperative. Cooperative of BMT Trans Mekar Sari Mandiri is the best cooperative at Tanjung Lago District Banyuasin Regency. The purpose of this study were to: (1) describe and measure service quality and member satisfaction of cooperative BMT Trans Mekar Sari Mandiri, (2) analyze the influence of service quality on member satisfaction of cooperative of BMT Trans Mekar Sari Mandiri, and (3) analyse the influence of each service quality dimension on member satisfaction of Cooperative BMT Trans Mekar Sari Mandiri. This reasearch used survey method (Explanatory Survey). and data was analized by multiple linear regression. The Population is 1056 member of Cooperative BMT Trans Mekar Sari Mandiri, and sample was taken randomly 66 people. The results showed that: (1) service quality of BMT Trans Mekar Sari Mandiri (with five dimension that is tangible, reliabitily, responsiveness, assurance, and emphaty), was in high catagory with average score 70.09 (93.33\% from ideal score), and member satisfaction of Cooperative BMT Trans Mekar Sari Mandiri was in high catagory with average core 46,33 $(96,52 \%$ from ideal score), (2) there is positive influence between service quality on member satisfaction of cooperative BMT Trans Mekar Sari Mandiri. Member satisfaction can be explained by the service quality as much as 73,9 percent. (3) Based on each quality service dimension, the member statisfaction was significantly inflluenced by the dimensions of tangible, responsiveness, and empathy, but not significantly influenced by reliability and assurence.
\end{abstract}

Keywords: Cooperative, Member Satisfaction, Service Quality.

\section{Introduction}

Cooperatives are an inseparable part of national development [1]. Cooperatives in Indonesia are based on Pancasila and the 1945 Constitution and are based on family principles. Article 33 of the 1945 Constitution places cooperatives as the cornerstone of the national economy. Cooperatives are an autonomous association of people who join voluntarily to meet their same economic, social and cultural needs and aspirations through democratically owned and controlled companies, with the aim of promoting the welfare of members. 
In its development a cooperative seeks to improve its services to gain the trust of members. One of the conditions for cooperatives to be successful in future competition is to try to achieve their goals by creating and retaining members. Cooperatives increase attention to the service quality and service strategy for enhanching the member satisfaction. Kasmir states that a company or cooperative must be able to provide the best service so that customer desires can be maximally fulfilled [2]. According to Hasibuan, cooperative services are cooperative businesses providing the best possible service to what is needed by members so that members get the ease of obtaining the goods services [3]. The superiority of service/uniqueness of cooperative products is generally triggered because it is known: the needs that can be satisfied by the product offered, the criteria for selecting customers, the factors that influence and the motives of customer behavior [4]. Although the services offered by cooperatives are in accordance with the tastes of members, but in providing poor service will cause members to be less satisfied. According to Quyet improving service quality is better for customers (cooperative members) and providing superior service will increase the satisfaction of cooperative members [5].

Member satisfaction is a feeling of pleasure or disappointment someone who appears after comparing the performance (results) of the product thought to the expected performance. Whether or not a member is satisfied after making a transaction depends on the employee's performance in meeting the expectations of the member [6]. If performance is below expectations, members are not satisfied. If performance meets expectations, members are satisfied. If the performance exceeds expectations, members are very satisfied or happy. According to Parasuraman, service quality is a measure of how good the level of service provided is in accordance with the wishes of the customer [7]. The dimensions of service quality consist of tangible, reliability, responsiveness, assurance, empathy [8]. Tangible (physical form) includes physical facilities such as buildings and equipment, employee appearance, communication facilities and other physical manifestations that can be of concern to customers [9]. Reliability is the ability that can be relied upon to provide services quickly, precisely, accurately and consistently so that it can satisfy members as customers. Responsiveness (responsiveness) is the personal desire of company staff and employees who consciously want to help customers and provide services as soon as possible so that they can satisfy customers Assurance covers the knowledge, abilities and skills, courtesy and trustworthiness of staff and employees so as to ensure customers are avoided from danger, risk, or doubt and disappointment. Furthermore, Emphaty (empathy) which includes individual/personal attention in understanding customer needs, ease of relationships, good communication and easy to understand. The attributes that exist in empathy, include: ease in establishing relationships, effective communication, personal attention, and understanding of the individual needs of customers [10]. Some research results show that service quality is positively related to customer satisfaction [1][11]-[13].

Trans Mekar Sari Mandiri BMT Cooperative is a multi-business cooperative or nonsacrificial syariah financial institution that was established as non-governmental groups. Therefore, it was different from banking goverment financial institutions and other non syariah financial institutions. Trans Mekar Sari Mandiri BMT Cooperative is used as a case of the best cooperatives in Banyuasin Regency. The presence of the Trans Mekar Sari Mandiri BMT Cooperative is very beneficial for its members because the Trans Mekar Sari Mandiri BMT Cooperative is very helpful in lending and borrowing money both in the short term and the long term. The formation of the cooperative is basically to serve the needs of its members so that member satisfaction will be achieved. Cooperative members will feel satisfied if the services provided are good and meet the needs of cooperative members. There was no 
information of the quality of service and satisfaction of members at the cooperative. The research was needed to observe "The Effect of Service Quality on the member Satisfaction of Trans Mekar Sari Mandiri BMT Cooperative at Tanjung Lago District, Banyuasin Regency, South Sumatra". In detail the objectives of this study are (1) to determine the quality of service levels and satisfaction of members of the Trans Mekar Sari Mandiri BMT cooperative in Tanjung Lago District, Banyuasin District, (2) analyze the influence of the dimensions of service quality which includes the Tangible dimension (physical manifestation), Reliability, Responsiveness, Assurance, and Empathy to the satisfaction of members of the Trans Mekar Sari Mandiri BMT Cooperative in Tanjung Lago District, Banyuasin Regency.

\section{Research Method}

The study was conducted in Tanjung Lago Subdistrict, Banyuasin Regency, South Sumatra, collected through direct interviews with respondents with questionnaire list. Samples taken randomly (Simple Radom sampling) are 66 members from a population of 1056 people.

Data were analyzed descriptively qualitatively and quantitatively according to variables and research objectives. The quality of service is measured in five dimensions, through its indicators, each ofwhich consists of 5 indicators/questions. While member satisfaction is measured from 4 aspects, each of which consists of 4 questions. Each question is measured on an ordinal scale (scoring) 1, 2, and 3, respectively for low, medium and high scores, so the total score for service quality ranges from 25 to 75 ; and the total score of member satisfaction ranges from 16 to 48 . To test the research hypothesis, namely: there is an effect of the dimensions of service quality on the satisfaction of members of the trans Mekar Sari Mandiri BMT cooperative used Multiple Linear Regression Analysis. And the data collected was tested for validity and reliability, as well as the requirements test for the Multiple Linear Regression Test.

\subsection{Hypothesis testing}

Measuring the magnitude of the effect of independent variables on dependent variable and also to measure the closeness of the relationship between $\mathrm{X}$ and $\mathrm{Y}$, regression analysis is used. Data analysis technique used to solve the problem is regression analysis. This analysis is used to determine and obtain a picture of the influence of Tangibles (X1), Reliability (X1), Responsiveness (X3), Assurance (X4) and Empathy (X5) on Member Satisfaction (Y). Data processing in this study was processed by with the Statistical Package for Social Science (SPSS) computer program [4]. The multiple linear regression was defined by equation:

$$
Y=\alpha+\beta_{1} X_{1}+\beta_{2} X_{2}+\beta_{3} X_{3}+\beta_{4} X_{4}+\beta_{5} X_{5}+e
$$

\section{Result and Discussion}

\subsection{Characteristics of Respondents}

Respondents in this study were 66 members of the Trans Mekar Sari Mandiri BMT Cooperative District. Tanjung Lago, Banyu Asin Regency. Characteristics of respondents 
include: age, sex, length of time being a cooperative member, formal education, and number of family members. The age of the respondents ranged from 17 to 60 years, with an average of 35 years, the sex of most women (86,4\%); long been a member of 1 to 11 years, with an average of 7.2 years. The formal education of respondents ranging from elementary to Bachelor, and most (81.82\%) have completed junior high school or more. Most respondents $(51.52 \%)$ have jobs as farmers, teachers, traders, civil servants, and self-employed; and $48.48 \%$ as housewives. The dominant occupation as a farmer $(31.82 \%)$. The number of family members ranges from 1 to 8 people, and most $(72.73 \%)$ have more than 4 family members. The duration of membership in the cooperative ranges from 1 to 11 years with an average of 6.98 years. Detailed description of the characteristics of the respondents as shown in Table 1.

Tabel 1. Respondent Charateristic of BMT Trans Mekar Sari Mandiri Cooperative

\begin{tabular}{clccc}
\hline No & \multicolumn{1}{c}{ Characteristic } & Criteria & Sum & Persentage \\
\hline 1. & Old (year) & $17-31$ & 23 & 34,85 \\
& & $32-46$ & 38 & 57,58 \\
& & $47-60$ & 5 & 7,57 \\
\hline 2. & Education & Elementary school & 12 & 18,18 \\
& & Middle school / equivalent & 32 & 48,48 \\
& & SMA / equivalent & 18 & 27,27 \\
& & Diploma / degree SD & 4 & 6,06 \\
\hline 3. & Competition work & House hold & 32 & 48,48 \\
& & Bussines & 1 & 1,52 \\
& & Farmer & 21 & 31,82 \\
& & PNS, Teacher, retired & 4 & 6,06 \\
& & Entrepreneur & 8 & 12,12 \\
\hline 4. & Number of family members & $2-3$ & 18 & 27,27 \\
& (person) & $4-5$ & 41 & 62,12 \\
& & $6-8$ & 7 & 10,61 \\
\hline 5. & Experience of being a & $1-4$ & 19 & 28,79 \\
& member of a cooperative & $5-8$ & 12 & 18,18 \\
& (years) & $9-11$ & 35 & 53,03 \\
\hline
\end{tabular}

\subsection{Service quality}

Service Quality in the BMT Trans Mekar Sari Mandiri cooperative is showed in the high category with an average score of 70.01 or $93.33 \%$ of the expected value. Analysis of each dimension shows that the dimensions of tangibles, reliability, responsiveness, and assessment are each high criterion. while the empathy dimension is showed the medium criteria. The value of each dimension in detail can be seen in Table 2 .

Table 2. Score of Service quality of BMT Trans Mekar Sari Mandiri cooperative

\begin{tabular}{llcccc}
\hline Dimension of Service quality & $\begin{array}{c}\text { Interval } \\
\text { score }\end{array}$ & Mean & $\begin{array}{c}\text { Percentage } \\
\text { of target }\end{array}$ & Criteria \\
\hline 1. & Tangibles (X1) & $7-15$ & 14,36 & 95,73 & high \\
\hline 2. & Reliability (X2) & $7-15$ & 13,94 & 92,93 & high \\
\hline 3. & Responsiveness (X3) & $7-15$ & 13,94 & 92,93 & high \\
\hline 4. & Assurance (X4) & $9-15$ & 13,41 & 89,40 & high \\
\hline 5 & Empathy (X5) & $7-15$ & 11,51 & 76,73 & medium \\
\hline
\end{tabular}


It can be seen from Table 2 that the highest score is on the tangible dimension and the lowest is on the empathy dimension. This shows that tangible is considered more in harmony with the expectations of cooperative members, while empathy is considered quite adequate. The results of this study are similar with Eliyawati et al [14] which was showed that cooperative members are very satisfy with the service from the physical aspect, and in the category are quite satisfied with the empathy dimension. The results of this study are slightly different from Sreeja ES [13], which shows that the tangible dimension best suits the expectations of members, while the lowest is assurance.

In this study tangible dimensions include indicators: the appearance of cooperative management, comfort of the building, ease in the service process, dicipline of the management in providing services, and access/ease of members in service requests. The reliability dimension includes indicators: the accuracy of the board in serving, the existence of clear service standards, the ability of the board to use tools in the service process, the ability of the board to pay attention to members' problems, and the ability of the board to complete tasks as promised. Responsiveness includes indicators: the ability of the board to respond to members, the speed of the board serving members, the accuracy of the board serving members, the accuracy of the board serving members, and the ability of the board to respond to member complaints. All four dimensions, all indicators included in the high category. Meanwhile, the empathy dimension includes the medium category, the indicators of which are: the management prioritizes the interests of the members, the friendliness of the board in serving members, the politeness of the board in serving members, the ability of the board to serve members without discrimination, and the ability of the board to respect each member.

\subsection{Members Satisfaction of Cooperative}

Members' satisfaction with the services of the Trans Mekar Sari Mandiri BMT Cooperative as a whole indicator ranges from 21 to 48 with an average of 46.33 (96.56\% of the expected value) and it was classified in the high category. When viewed in all aspects, all indicators are also included in the high criteria, although there are variations in the score, as in Table 3.

Tablel 3. Scoreof Members Satisfaction of Cooperative BMT Trans Mekar Sari Mandiri

\begin{tabular}{llcccc}
\hline & \multicolumn{1}{c}{$\begin{array}{c}\text { Indicator Members } \\
\text { Satisfaction }\end{array}$} & $\begin{array}{c}\text { Interval } \\
\text { score }\end{array}$ & Mean & $\begin{array}{c}\text { Percentage of } \\
\text { target }\end{array}$ & Criteria \\
\hline 1. & Members' Expectations (Y1) & $4-12$ & 11,47 & 95,58 & high \\
\hline 2. & Overall satisfaction (Y2) & $7-12$ & 11,62 & 96,83 & high \\
\hline 3. & Commitment (Y3) & $4-12$ & 11,73 & 97,75 & high \\
\hline 4. & Willingness to recommen(Y4) & $6-12$ & 11,51 & 95,91 & high \\
\hline 5. & Member Satisfaction (Y) & $21-48$ & 46,33 & 96,52 & high \\
\hline
\end{tabular}

It can be seen from Table 3 that the highest score is an indicator of commitment and the lowest score is an indicator of the suitability of members' expectations. The suitability of the members' expectations is measured through 4 questions, namely: the level of pleasure in joining the cooperative, the service according to need, whether the provision of capital in accordance with the needs of members, and whether the Cooperative provides services and facilities in the transaction. Overall satisfaction includes indicators: whether the board is good 
at serving, whether during the transaction the board is friendly, whether members are satisfied with the speed of response in dealing with complaints, whether the board always smiles in serving members. Commitment is measured through indicators: always want to be a member, a sense of ownership of the cooperative, whether the member agrees with the cooperative's predetermined cooperative rules, whether the member wants the cooperative to be more advanced. Furthermore, the willingness to recommend is measured by whether advising friends or relatives to become members of the cooperative, whether promoting the cooperative to friends or relatives, whether notifying the products offered to friends or relatives, and whether the benefits obtained if a member of the cooperative. The results of the study showed that for all indicators included in the high criteria, the average achievement score was more than $95 \%$.

\subsection{Effect of Service Quality on Member Satisfaction}

It was found that the service quality of the BMT Trans Mekar Sari Mandiri Cooperative affected the member satisfaction. This is indicated by Table 4 (Model Summary) and Table 5 (Anova) that the calculated $F$ value of 37.776 is greater than the $F$ table of 2.37 on significance level of 0.05 . This situation means that simultaneously tangibles, reliability, responsiveness, assurence, and empathy dimensions affect the member satisfaction supporting by the Adjusted $\mathrm{R}^{2}$ Value of 0.739 . This means that $73.9 \%$ of member satisfaction variables can be explained (influenced) by service quality variables, while the remaining $26.1 \%$ is influenced by other variables not analyzed in this study.

Tabel 4. Model Summary

\begin{tabular}{ccccc}
\hline Model & $\mathrm{R}$ & R Square & Adjusted R Square & $\begin{array}{c}\text { Std. Error of the } \\
\text { Estimate }\end{array}$ \\
\hline 1 & $.871^{\mathrm{a}}$ & .759 & .739 & 1.88961 \\
\hline
\end{tabular}

a. Predictors: (Constant), $X_{5}, X_{4}, X_{3}, X_{2}, X_{1}$

Tabel 5. Dan ANOVA ${ }^{b}$

\begin{tabular}{llccccc}
\hline & Model & Sum of Squares & df & Mean Square & F & Sig. \\
\hline 1 & Regression & 674.428 & 5 & 134.886 & 37.776 & $.000^{\mathrm{a}}$ \\
\cline { 2 - 7 } & Residual & 214.238 & 60 & 3.571 & & \\
\cline { 2 - 5 } & Total & 888.667 & 65 & & & \\
\hline
\end{tabular}

a. Predictors: (Constant), $X_{5}, X_{4}, X_{3}, X_{2}, X_{1}$

b. Dependent Variable: $(\mathrm{Y})=$ member satisfaction

Partial analysis of the effect of service quality dimensions on cooperative member satisfaction can be seen from the results of calculations with multiple linear regression as shown in Table 6. 
Tabel 6. Coefficients ${ }^{\mathrm{a}}$

\begin{tabular}{|c|c|c|c|c|c|c|}
\hline & \multirow[t]{2}{*}{ Model } & \multicolumn{2}{|c|}{$\begin{array}{c}\text { Unstandardized } \\
\text { Coefficients }\end{array}$} & \multirow{2}{*}{$\begin{array}{c}\text { Standardized } \\
\text { Coefficients }\end{array}$} & \multirow[t]{2}{*}{$\mathrm{t}$} & \multirow[t]{2}{*}{ Sig. } \\
\hline & & B & Std. Error & & & \\
\hline \multirow[t]{6}{*}{1} & (Constant) & 8.451 & 2.887 & & 2.927 & .005 \\
\hline & X1 (tangible) & .782 & .406 & .279 & 1.924 & .059 \\
\hline & X2 (reliability) & .174 & .294 & .080 & .593 & .556 \\
\hline & X3 (rsponsivn & .399 & .241 & .185 & 1.656 & .103 \\
\hline & X4 (asurance) & -.020 & .193 & -.011 & -.104 & .918 \\
\hline & X5(emphaty) & 1.311 & .345 & .422 & 3.801 & .000 \\
\hline
\end{tabular}

a. Dependent Variable: KpsAnggota

From Table 6 the Regression equation is obtained as follows:

$$
Y=8,451+0,782 X_{1}+0,174 X_{2}+0,399 X_{3}-0,020 X_{4}+1,311 X_{5}
$$

Partial analysis of each dimension of service quality, shows that the significant dimensions of influence on member satisfaction are: tangible dimensions (X1), responsiveness (X3), and empathy (X5) significant effect on level of 0.10. Otherwise the reliability (X2) and Assurance (X4) had no significant effect. It is diferent from Oktavia et al. [15], that members satisfaction was not infleunced by the dimensionss of responsiveness. Value of $\boldsymbol{a}=8.451$ means that if X1, $\mathrm{X} 2, \mathrm{X} 3, \mathrm{X} 4$, and $\mathrm{X} 5$ are 0 , then member satisfaction is 8.451 . Coefficient $\square 1=0.782$, tangible regression coefficient 0.782 means that if there is an increase in $\mathrm{X} 1$ (tangible) by 1 point it will increase member satisfaction (Y) by 0.782 assuming $\mathrm{X} 2, \mathrm{X} 3, \mathrm{X} 4$ and $\mathrm{X} 5$ are constant. Coefficient $\square 3=0.399$, tangible regression coefficient 0.399 means that if there is an increase in X3 (responsiveness) by 1 point it will increase member satisfaction (Y) by 0.399 assuming $\mathrm{X} 1, \mathrm{X} 2, \mathrm{X} 4$ and $\mathrm{X} 5$ are constant. Coefficient $\square 5=1.311$, regression coefficient 1.311 means that if there is an increase in $\mathrm{X} 5$ (emphaty) by 1 point it will increase member satisfaction (Y) by 1.311 with the assumption that X1, X2, X3, and X4 are constant. Member satisfaction in this study was measured through 4 aspects / indicators: conformity with member expectations (Y1), overall member satisfaction (Y2), commitment (Y3) and willingness to recommend (Y4). The correlation between each dimension of service quality with the dimensions / aspects of the members of the cooperative can be seen in Table 7.

Tabel 7. Coefficient Correlation between dimensions of service quality with dimensions /aspects of member satisfaction of cooperatives

\begin{tabular}{lcccccc}
\hline & \multicolumn{6}{c}{ Variabel/Dimension/Indicator } \\
\cline { 2 - 7 } Dimension/Indicator & $\begin{array}{c}\text { Service } \\
\text { quality } \\
(\mathrm{X})\end{array}$ & Y1 & Y2 & Y3 & Y4 & $\begin{array}{c}\text { Member } \\
\text { satisfaction } \\
(\mathbf{Y})\end{array}$ \\
\hline Tangible $(\mathrm{X} 1)$ & $0,748^{* *}$ & $0,590^{* *}$ & $0,653^{* *}$ & $0,406^{* *}$ & $0,732^{* *}$ & $0,747^{* *}$ \\
\hline
\end{tabular}




\begin{tabular}{lrrrrrr}
\hline Reliability (X2) & $0,855^{* *}$ & $0,767^{* *}$ & $0,619^{* *}$ & $0,535^{* *}$ & $0,729^{* *}$ & $0,900^{* *}$ \\
\hline Responsiveness (X3) & $0,748^{* *}$ & $0,422^{*}$ & $0,619^{* *}$ & $0.472^{* *}$ & $0,533^{* *}$ & $0,548^{* *}$ \\
\hline Assurance (X4) & $0,867^{* *}$ & $0,433^{*}$ & $0,350^{* *}$ & $0,587^{* *}$ & $0,635^{* *}$ & $0,720^{* *}$ \\
\hline Emphaty (X5) & $0,700^{* *}$ & 0,479 & $0,619^{* *}$ & $0,410^{*}$ & $0,565^{* *}$ & $0,613^{* *}$ \\
\hline Member satisfaction (Y) & $0,856^{* *}$ & $0,785^{* *}$ & $0,723^{* *}$ & $0,631^{* *}$ & $0,793^{* *}$ & 1,00 \\
\hline Service quality (X) & $1,00^{* *}$ & $0,744^{* *}$ & $0,560^{* *}$ & $0,469^{* *}$ & $0,669^{* *}$ & $0,856^{* *}$ \\
\hline
\end{tabular}

It can be seenfrom Table 7 that partially all dimensions of service quality (X1, X2, X3, X4, and X5) correlate with aspects/indicators of cooperative member satisfaction (Y1, Y2, Y3, and Y4). Correlation coefficient values vary from low to high categories. The lowest coefficient coefficient $\mathrm{Rs}=0.350$ is the correlation between assurance (X4) with overall member satisfaction (Y2); while the highest correlation is Rs $=0.767$, which is the correlation between reliability (X2) with the compatibility with the expectations of members (Y1).

Based on correlation it can be seen that each indicator is highly correlated with the variable, all of them are worth Rs greater than 0.6. The lowest value of $R s=0,631$ ie the correlatiod on cerelation value $\mathrm{n}$ between $\mathrm{Y} 3$ and $\mathrm{Y}$, and the highest value of Rs $=0.867$, which is the correlation between $\mathrm{X} 4$ and $\mathrm{X}$. Therefore, all indicators are valid as a measure of the variable.

\section{Conclusion}

Service quality that includes tangible dimensions, reliability, responsiveness, assurance, and empathy, at the Trans Mekar Sari Mandiri BMT Cooperative as a whole including high categories. Service quality that includes Tangible, Reliability, Responsiveness, assurance, and empathy dimensions simultaneously has a positive effect on the satisfaction of members of the Trans Mekar Sari Mandiri BMT cooperative. Partially the dimensions of service quality which significantly influenced member satisfaction are: tangible dimensions (X1), responsiveness (X3), and empathy (X5), but the dimensions of reliability (X2) and Assurance (X4) had no significant effect.

\subsection{Acknowledgments}

Acknowledgments was addressed Sriwijaya University through the Sriwijaya University Research Institute, has provided research grants. We also appreciate to and all respondents, key informants, and stakeholders involved in the Cooperative BMT Trans Mekar Sari Mandiri who have assisted in the implementation of this research.

\section{References}

[1] N. Tasunar, "Kualitas Pelayanan Sebagai Strategi Menciptakan Kepuasan Pada Pangkalan Pendaratan Ikan (PPI) Moro Demak," J. Sains Pemasar. Indones. (Indonesian J. Mark. Sci., vol. 5, no. 1, pp. 41-62, 2006.

[2] S. E. Kasmir, "Bank dan Lembaga Keuangan Lainnya Edisi Revisi," 2018.

[3] S. P. Malayu Hasibuan, "Dasar-dasar Perbankan." Penerbit PT Bumi Aksara: Jakarta, 2005.

[4] Y. Wirasasmita, Komunikasi Bisnis dan Profesional. Bandung: Remaja Rosdakarya, 2005.

[5] T. Van Quyet, N. Q. Vinh, and T. Chang, "Service quality effects on customer satisfaction in banking industry," Int. J. u-and e-Service, Sci. Technol., vol. 8, no. 8, pp. 199-206, 2015. 
[6] P. Kotler and K. L. Keller, "Manajemen Pemasaran jilid 1 edisi 13," Jakarta: Erlangga, 2009.

[7] F. Tjiptono and G. Chandra, "Service, quality \& satisfaction," Yogyakarta Andi Offset, 2005.

[8] T. S. Joesron, "Manajemen Strategik Koperasi," Graha Ilmu, Yogyakarta, 2005.

[9] A. Subagyo, "Marketing In Business: Studi Kasus UMK \& LKM," Ed. Asli, Penerbit Mitra Wacana Media, Jakarta, 2010.

[10] A. M. Joshi and K. G. Sankaranarayanan, "No Title," Int. J. Sci. Res., vol. 5, no. 11, pp. 738743, 2016.

[11] S. B. D. Parani, A. M. Palampanga, C. Fattah, and Vitayanti, "The Effect of Service Quality and Performance of Cooperative on Cooperative Image and Its Impact to the Satisfaction of Cooperative Member in the Central Sulawesi Province," Eur. J. Bussiness Manag., vol. 9, no. $11,2017$.

[12] G. Panaris, "The Effects of the Service Quality Dimensions on Customer Satisfaction and Customer Loyalty: The Experience Of the Paphos Cooperative Bank In Cyprus.” Master of Business Administration, Shcool of Business, Neapolis University Pafos, 2015.

[13] E. Sreeja, "A study on service quality of co-operative banks with special reference to Thrissur District," Int. J. Appl. Res., vol. 2, no. 10, pp. 01-04, 2016.

[14] W. Eliyawati, N.Sutjipta, and I. G. S. A. Putra, "The Quality of Service and The levelof Members Stiafaction of The Suralerata Village Unit of Cooperative, West Selemadeng Sub District," J. Manaj. Agribisnis, vol. 4, no. 1, pp. 68-80, 2016.

[15] O. Soverani and T. Karyani, "The Effect of Service Quality to the Satisfaction of the member of Cooperative Product of Margamulya Coffe in Subdistrict Pagalengan," J. Agrisep, vol. 16, no. 2, pp. 155-164, 2017. 